\title{
TIME TOKEN TECHNIQUE TO IMPROVE STUDENTS' LEARNING ACTIVITY AND COMMUNICATIVE COMPETENCE
}

\author{
Bambang Susatyo \\ SMK Negeri 2 Temanggung
}

\begin{abstract}
The purpose of this research is to know the effectiveness of cooperative learning time token towards student's learning activity and communicative competence in speaking English. This research uses Classroom Action Research procedures. The research consists of two cycles, each comprises four phases, namely planning, acting, observing and reflecting. The students of SMK N 2 Temanggung semester 1 2019/2020. are the subject of the research. To get data, the writer use Brown's Scale of Test of Spoken English. While for students' activities, the writer uses a set of observation sheet to observe the activity of the students in class. The research reveals that the uses of Time token technique in English class has increased the students' learning activities from $68 \%$ in Pre-cycle to $78 \%$ in cycle 1 and $80 \%$ in cycle 2 . The Communicative competence in speaking English has increased from 74 to 78 in cycle 1 and 81 in cycle 2
\end{abstract}

Key words: hots, taxonomy, curriculum 2013, english achievement

\section{INRODUCTION}

The goal of language teaching is to develop what Hymes referred to as communicative competence. Communicative competence refers to a learner's ability to use language to communicate successfully. Canale and Swain (1980) defined it as composing competence in four areas; words and rules, appropriacy , cohesion and coherence and use of communication strategies(www.teachingenglish.org.uk).

Communicative competence is also found in Canale and Swain (1980) which four dimensions of communicative competence are identified ; grammatical competence, socio linguistic competence, discourse competence and strategic competence.

The problems encountered at schools in communication is the low level of communicative competence. This can be caused by inactivity of students and inappropriate choice of teaching approach in the case of low communicative competence. At the class the writer uses as the place of research the average of communicative competence in the topic of asking and giving opinion is only 74 . While the students who gained the Minimum mastery score is only 18 students or $52 \%$ of the students. Some 17 other students did not reach the minimum score. On the other side, the average of activity level of the students is only $68 \%$.

That's why the writer tries to use time token technique to improve the students' activity and communicative competence. 


\section{Learning activity}

Activity is being active or lively, thing to be done; occupation (Hornby 1973). Learning is a change which happens within one's self as a result of studying (Jumarah,2013). And learning activity is defined as various activities given to learners in the process of teaching and learning( Hamalik,2013). The success of learning largely depend on the students' learning activity. So students should be active in learning a language. In every learning process there should be active learning (Sutikno,2014). Active learning is aimed at optimizing all the potentialities possessed by the students, so that all students can gain satisfactory learning result in line with their capacity. Besides, active learning is to keep the students focus on their learning.

From the description above, if an activity is connected with learning activity it can be defined as an activity in teaching and learning process which can arouse interaction skills between students so the students can get meaningful learning experience and can improve their understanding.

Learning activity plays important role in the teaching and learning process because it can increase the quality of learning which in turns, can improve the students' mastery. Learning activity needs students' involvement physically, mentally, emotionally and intellectually.

There are some activities according to scholars. Deidrich as cited by Sardiman (2011) makes as many 177 kinds of student activities which are classified into eight groups, they are; 1) visual activities, which comprises activities such as; reading, seeing, watching, observing, doing experiment, and the like, 2) oral activities, which include stating, defining, asking, giving advice, expressing opinion, interrupting and having a discussion, 3) listening activities, which include listening to teacher's explanation, listening in group discussion, listening to the presentation, listening to other group opinion, 4) writing activities which include taking notes from teacher's explanation, rewriting the result of a discussion, writing presentation of other group's presentation, doing test, 5) drawing activities which consists of activities related to drawing, make chart , making diagrams, 6) motor activities, which has relation with classroom activities such as doing experiment, giving a presentation, responding other students' opinion explaining and asking questions during teaching and learning process, 7) mental activities, which comprise some activities related to having discussion, remembering, problem solving, analyzing, finding the relations between two phenomena and drawing a conclusion, 8) emotional activities, which are related to emotion, such as taking interest, feel bored, happy, excited, brave, calm and nervous.

\section{Communicative Competence}

Communicative competence is an aspect which enables people to express and interpret interpersonal message in a certain context. It depends on the cooperation among the committed participants. Communicative competence gives 
stress on the function of a language in communication rather than master the rules of the language..The rules of the language has function to monitor the form utterance.

The nature of Communicative competence according to Tarigan (1990) include: a) knowledge about grammar and vocabulary of the language, b) how to use the language (how to start end a conversation, about what topic to discuss in different situation, idioms to greet others in different situation), c) how to use and give response to different utterances like asking and giving apology, thanking and inviting people, d) how to use a language properly and satisfactorily. So, a person who wants to speak to another, should know his social background, his relation with other people and types of language which can be used on a certain occasion.

Theoretically, communicative competence has at least four components, as stated by Canale and Swain(1980) as cited by Jason Beale: a)Grammatical competence, is a the mastery of rules of a language, either verbal or non-verbal like phonology, orthography, vocabulary, word formation, and syntax. It is what Chomsky calls language competence, that is knowledge about grammar and ability to use it in communication, but it is argued by Savignon (1983) that the stress is not on the rules but on the use of the rules, thus students' communicative competence is measured by how well they produce correct utterances according the language rules, not by how well they memorize the rules, b) Sociolinguistic competence, mastery of a language rules in the socio-cultural context. It is required to understand specific factors such as role and status of the speaker, purpose and function of interaction and so on. So it is competence of interdiscipline field, in which students can use the language properly, pragmatically, and contextually suitable, c) Discourse competence, is ability to give intepretation about topic of a paragraph, chapter or book, using cohesion and meaning . in other word we can say that discourse competence is ability to intepret sentence structure or idioms to build cohesion and meaning. d) Strategic competence, is abiliy to facilitate efectivity of communication and prevent the disfluenciess in communication among speakers. Giving gestures, signs, or explaining in simpler words to make communication run smoother are common things which can be called as strategic competence.

\section{Cooperative learning with Time Token Technique}

Time Token is one practice of Cooperative Learning. Slavin(1995) defines Cooperative learning as instruction program in which students work in small groups to help one another in mastering a lesson.

There are some principles of cooperative learning. There are 8 principles in cooperative learning. 1) Heterogeneous grouping, 2) Cooperative skill, 3) .Group autonomy, 4) Simultaneous interaction, 5) Equal participation, 6) Personal reponsibility.7) Positive interdependence, 8) Cooperation as value

\section{Definition of Time Token}

Time token derives from the words time and token. Time refers to portion or measure of time. While token means sign, evidence, or mark of something 
(Hornby, 1973). Time Token is a cooperative learning technique which is charactarized by time signal or time limit. Time limit is aimed at evoking and motivating students in exploring their thought and expressing ideas. This technique is suitable to develop social skill or to avoid student's domination upon other students' silence. According to Zainal (2013), Time Token Cooperative Learning is a teaching technique to make students active in expressing their ideas.

Time Token is a kind of cooperative Learning which was developed by Arends ( Supriono, 2010). In Time Token technique, a student is given four pieces of coupons, each coupon contains fifteen minutes of speech time.. Thus a student has one minute to speak.

Students who have used the four coupons, have no more time to speak, so that all students have equal chance to speak. In the research, the writer makes groups of three students who have heterogeneous speaking ability. The topic is "asking and giving opinion". In the group, three students work together and peerteach one another to give opinion about a certain topic. The team's opinion should be harmonious and coherent. They should also support one another. For example, when the teacher give a topic of smoking, when a student argues if smoking is bad, the other members should support it.

In the next level, students should work together in the form of debate to give opinion about a controversial topic such as, That students should be prohibited to bring cell phone to school" or topic like " That the government should not move the capital city". The topic should be familiar to the students.

According to Supriyono, (2009) the steps or syntax in teaching using Time Token Technique is as follows; a) Prepare the class to have a discussion, b) Each student is given four coupons, in which each coupon worth fifteen seconds for speaking. c) If a student has finished with one coupon which means he has spoken for fifteen seconds, the coupon should be submitted to his friend .d) students who have used the all coupons (four coupons) must not speak to give opinion anymore, while students who is still holding coupons can go on speaking until he uses up all the coupons.

\section{METHOD}

The research was done from Juli-September 2019 in SMK Negeri 2 Temanggung. The subjects are students of XI Accounting 1 2019/2020, amounted 35 students. The object of the research is the application of Time Token technique of Cooperative Learning.

The data are taken from students, documents and other teacher as collaborator. Data collection are taken by observation, and test. Observation focuses on students' activity and application of Time Token Technique. The test is in the form of post test. It is used to measure students' communicative competence. The test instrument which is used is Brown's Test of Spoken English (TSE) rating scale (Brown, 1995).

The students activities derives from Diedrich (2015)as cited by Sardiman (2011) which comprise a) visual activities, b) oral activities, c) listening activities, 
d) writing activities, e) drawing activities, f) motoric activities, g) mental activities, and $\mathrm{h}$ )emotional activities

The test was conducted after the teaching learning process. The test used Brown's Test of Spoken English (TSE) rating scale. The test is to measure the students'global capability or students' communicative competence.

Table 1 Students' Communicative Commpetence

\begin{tabular}{|c|c|c|c|c|c|c|}
\hline $\begin{array}{c}\mathrm{N} \\
\mathrm{O}\end{array}$ & Nama & $\begin{array}{c}\text { No effective } \\
\text { communicatio } \\
\text { n: no evidence } \\
\text { of ability to } \\
\text { perform task. }\end{array}$ & $\begin{array}{c}\text { Communica- } \\
\text { tion } \\
\text { generally not } \\
\text { effective: } \\
\text { task } \\
\text { generally } \\
\text { performed } \\
\text { poorly. }\end{array}$ & $\begin{array}{c}\text { Communica } \\
\text {-tion } \\
\text { somewhat } \\
\text { effective: } \\
\text { task } \\
\text { performed } \\
\text { somewhat } \\
\text { competently. }\end{array}$ & $\begin{array}{l}\text { Communica } \\
\text {-tion } \\
\text { generally } \\
\text { effective: } \\
\text { task } \\
\text { performed } \\
\text { competently }\end{array}$ & $\begin{array}{l}\text { Communica- } \\
\text { tion almost } \\
\text { always } \\
\text { effective: task } \\
\text { performed } \\
\text { very } \\
\text { competently. }\end{array}$ \\
\hline & & $20(19-33)$ & $30(35-48)$ & $40(50-67)$ & $50(68-84)$ & $60(85-100)$ \\
\hline 1 & $\begin{array}{l}\text { Afifatul K } \\
\text { Amanda }\end{array}$ & & & & & \\
\hline 2 & Amelia & & & & & \\
\hline 3 & Andri Juni A & & & & & \\
\hline
\end{tabular}

Table 2: Classification of test result

\begin{tabular}{ccc}
\hline Range & Category & Remark \\
$85<\mathrm{x} \leq 100$ & excellent \\
$71<\mathrm{X} \leq 85$ & good \\
$55<\mathrm{X} \leq 71$ & fair \\
$20<\mathrm{X} \leq 55$ & bad \\
\hline
\end{tabular}

The result of students' activity was measured in the process of teaching and learning by collaborator

Students' activities were then analyzed by deciding the average of students' activity and then classified as follow

Table 3: Classification of class observation result

\begin{tabular}{ccc}
\hline No & Rage & Category \\
\hline 1 & $0 \%-55 \%$ & Low \\
2 & $56 \%-65 \%$ & Sufficient \\
3 & $66 \%-75 \%$ & Moderate \\
4 & $76 \%-85 \%$ & High
\end{tabular}


Very high

To measure students' communicative competence the writer uses oral test . The result is then analysed to decide the mastery position. The level of mastery is 75. To count the percentage of students' mastery, he uses the formula of:

$$
\begin{gathered}
\text { Percentage } \quad\left(\begin{array}{c}
\%) \\
\text { number of students who gain master level }
\end{array}\right. \\
\text { total of students }
\end{gathered}=
$$

The increase of students' learning result is decided by counting average of test result of every cycle. The increase of individual test result is gained by comparing grades between one cycle with another.

\section{Research Design}

This research applies classroom action research(CAR) which includes four stages namely, planning, acting, observing and reflecting. The research consists of two cycles. Each cycle consist of three meetings. In the cycle 1, the planning is based on the pre-test result of the students' communicative competence test and students activity. The activity is in he form of asking and giving opinion. While on the cycle 2 the activity still uses cooperative learning of Time token in the form of mini debate. In the debate, the topics are taken from the problems the students feel and encounter in their daily life.

\section{Cycle 1 \\ a. Planning}

After reflecting on the unsatisfactory results of the competency test, the writer then took a step to conduct Classroom Action Research (CAR). The first step is planning. Planning in cycle I is carried out as an effort to solve all the problems found in the initial observation and preparation required for the action stage. Planning includes: 1) Preparation of cycle I RPP, 2) Preparation of student activity indicators for cycle 1,3) Development of speaking communicative competency assessment tools for cycle 1.4) Formulation of discussion topics for cycle 1, 5) Forming groups, each group consisting of 3 students, 6) Making cards or tokens of $4 \times 35=140$ cards, 7) Compilation of learning power points

\section{b. Acting}

The action stage is the implementation of a learning plan that has been prepared in accordance with the Time Token cooperative learning technique. The actions to be carried out in this research are as follows:

According to Supriyono, (2009) the steps for cooperative learning using the time token technique are:

1) Conditioning the class to carry out discussions (cooperative learning). The teacher explains the procedure that will be carried out in today's lesson, namely 
the cooperative learning of the Time Token technique. Students are explained that they will be given four cards. Each card costs fifteen seconds. Students may spend the four cards. After spending four cards the students are not allowed to talk anymore.

2) The teacher explains the topics that must be discussed by each group, for example

3) regarding their opinions about sports, reading, helping parents and so on. At a more difficult stage, students discussed the topic of prohibiting bringing cell phones to schools, moving the capital, prohibiting smoking in public places and so on.

4) Students discuss in their groups. In the same group, students must put forward one

5) language, meaning that if they do not agree with smoking then all must state things that support each other.

6) After that students present the results of the discussion. All groups are given time to

7) present. After each time speaking +/- 15 seconds, students submit one card. The student may continue speaking until the card in his hand runs out.

8 ) In cycle one only light topics were discussed while in cycle 2 students were invited

9) to debate topics that were viral, for example the prohibition of bringing cellphones to school or other topics.

c. Observing

The third step of this research is observation. This activity is carried out during the learning process using the observation sheet that has been prepared. Things that are not covered in the observation sheet will be recorded in the field note sheet. The things that are observed during the learning process are learning activities and activities of teachers and students during the learning process.

\section{d. Reflecting}

Reflection is the stage of assessment or evaluation of the implementation of cycle I actions which are used as consideration for planning the next cycle. If the expected results have not been achieved, improvements are made to be carried out in the next cycle.

\section{Cycle 2}

The second cycle action plan is intended as a result of reflection and improvement on the implementation of learning in cycle I.

\section{a. Planning}

After reflecting on the unsatisfactory results of the cycle 1 test, the writer then planned changes. The first step is planning. Planning in cycle II is carried out as an effort to solve all the problems found in cycle 1 and the preparation needed for the action stage. Planning includes improvements that are considered unsuccessful in cycle I. Planning includes: 1) Preparation of cycle II RPP, 2) Preparation of student activity indicators for cycle 2., 3) Development of speaking 
communicative competency assessment tools for cycle, 4) Formulation of topics to be discussed (debate format with motion), 5 ) Forming groups, each group consisting of 3 students. In this case, speakers 1, 2 and 3 are appointed for each group. With the addition of material about the duties of each speaker and a description of the affirmative and negative groups.6)The previous cards amounted 140 can still be used.

\section{b. Acting .}

The action stage is the implementation of a learning plan that has been prepared in accordance with the Time Token cooperative learning technique. The actions to be carried out in this research are as follows:

The steps for cooperative learning using the time token technique are:

1) Conditioning the class to carry out discussions (cooperative learning). The teacher explains the procedure that will be carried out in today's lesson, namely the cooperative learning of the Time Token technique. Students are explained that they will give their opinion in the form of an English debate. Students are given six cards. Each card costs fifteen seconds. Students may spend the six cards. After finishing six cards students are not allowed to talk anymore.

2) The teacher explains the topics to be discussed in a debate format by each group. They will be divided into two groups, namely the affirmative team (positive team) and the opposition team (negative team). They will argue on a topic, for example "That the students should not be allowed to bring cell phone to school." The positive team will support the motion, namely the team must work together to ensure that schools should not allow students to bring cell phones to school. Meanwhile, the negative team must state the opposite, namely they support students to bring cell phones to school. They must support each other with the reasons and benefits of bringing cellphones to school. While the positive team had to find reasons why they didn't allow students to bring cell phones or their bad aspects. The talk was arranged from the first speaker on the positive team, followed by the first speaker on the negative team. Then the positive team speaker was forwarded to the two negative team speakers. Speakers to the three positive teams get the next turn and are followed by speakers to the three negative teams. For speakers who have not finished their speaking cards, they are still allowed to speak in their respective roles. That is, the positive team speaker must refute the negative team's arguments and support the team (positive) and vice versa. Because it is a daily topic, the number of cards is increased to six cards.

3) Students have discussion in their groups. In the same group, students must speak one language, meaning that they become a positive team with the motion "That students should not be allowed to bring cellular phone to school". Team members must determine the team line (group attitude, for example, agreeing with the prohibition of bringing cell phones to school). looking for a point of view or point of view, for example from an educational point of view and the bad effects of cell phones. Meanwhile, the negative team group's attitude was against by prohibiting students from carrying cell phones. They first worked in 
groups, then make their own speech texts. They also have to help each other out.

4) After that students present the results of the discussion. All groups are given time to present. After each time speaking +/- 15 seconds, students submit one card. The student may continue speaking until the cards in his hand (six) run out.

5) In cycle one, the topics discussed were light topics, while the topics discussed in cycle

6) 2 were viral topics, for example the prohibition of bringing cell phones to schools or moving the capital.

c. Observing

The third step of this research is observation. In cycle II the observation is carried out in the same way as the steps in cycle I. Only in this cycle is it done more carefully. The things that are observed during the learning process are learning activities with debates and activities of teachers and students during the learning process.

\section{d. Reflecting.}

Reflection is the stage of assessment or evaluation of the implementation of cycle II actions which are used as material for consideration whether the research will continue or is considered successful enough and can be stopped in cycle II. If both of the predetermined indicators have been fulfilled, then the research is considered complete because all indicators have been achieved, but one or both have not been achieved, the research will continue to cycle 3

\section{FINDINGS AND DISCUSSION}

\section{Description of Initial Conditions}

One of the English materials for odd semester XI class is about asking and giving opinion. In this material the most important goal is for students to be able to give an opinion about something or phenomenon that is around us. There are many interesting topics that can be discussed, for example opinions on English lessons, smoking, bringing cell phones to school, sports, reading, to the issue of moving the capital city which is just getting busy in our country. Instead of being able to express complicated opinions about moving the capital city, students are mostly silent and less active. They dare not try to express their opinion. If anyone tries they are still with a sentence or two. They appear afraid and doubtful even though they have been motivated to try.

The results of the oral test related to this material were only 74,2 . Levelofmastery was only $54 \%$. And the level of student activity is only $68 \%$. The author thinks of trying a strategy, namely the time token, a learning strategy that provides speaking quota. Each student is given four cards so that they spend the four cards in their hand.

\section{Research Result}


The results of observations in cycle 1 were recorded in the prepared observation sheet. From the results of observations of student activities by observer 1, the following data were obtained:

Table 3.Observation results of student learning activities in cycle 1

\begin{tabular}{llcc}
\hline NO & Kind of activities & Percentage & Criterion \\
\hline 1 & Visual activity & $80 \%$ & High \\
2 & Oral activity & $81 \%$ & High \\
3 & Listening activity & $76 \%$ & High \\
4 & Writing activity & $83 \%$ & High \\
5 & Drawing activity & $74 \%$ & Moderate \\
6 & Motor activity & $76 \%$ & High \\
7 & Mental activity & $79 \%$ & High \\
8 & Emotion activity & $76 \%$ & High \\
\hline & Average & $78 \%$ & High \\
\hline
\end{tabular}

The data were obtained from observations of observer 1 during cycle 1 at the second and the third meeting. From the data it can be seen that student activity during learning is in the high category $(78 \%)$. Oral activity is in the high category $(81 \%)$, much better than during the pre-cycle, which is $34 \%$. Students have the courage to express their opinions or respond to other students' opinions. The cards that are held by students are what encourage students to express their opinions. Writing activity is the highest activity (83\%). This can be understood because students prepare oral opinions by writing their opinions in advance so that their speech becomes more orderly and can be improved. In addition, to be able to measure how long a student can express his opinion. While the results of the students' oral tests in cycle 1 are as follows:

Table 4 Test Results of Cycle 1

\begin{tabular}{cccc}
\hline NO. & Remark & $\begin{array}{c}\text { Score/number } \\
\text { of students }\end{array}$ & Percentage \\
\hline 1 & Highest Score & 85 & \\
2 & Lowest score & 72 & \\
3 & Average & 78 & \\
4 & Number of students reach the mastery level & 31 & $89 \%$ \\
5 & Number of students don't reach the & 4 & $11 \%$ \\
6 & mastery level & & $78 \%$ \\
\hline
\end{tabular}

The results of the cycle 1 test showed that the average score obtained by students was 78 with the highest score of 85 and the lowest score of 72 . The number of students who completed learning was $89 \%$ of students who received a 
minimum score of 75 . For classical completeness, it was obtained $78 \%$, which means $78 \%$ of the material given absorbed by students. Thus, cooperative learning of the Time Token technique brings better results.

From the results of the analysis of the results of the action and the data obtained in the implementation of cycle 1 activities, it can be reflected as follows:

1) Students have difficulty composing opinions in English. By cooperating with their group mates, they can slowly improve their speaking skills. From those who do not dare to speak to be more courageous, from those who can only say one sentence to 2,3 or four sentences.

2) At first, group cooperation did not go smoothly, the teacher had to remind students to further increase their cooperation because in cycle 2 there would be demands for teamwork that had to be more solid, namely a form of debate.

3) Card usage is still not smooth. When engrossed in talking, many students forgot that they had to put down a card after 15 seconds, which was marked by another friend. At the third meeting it went well.

4) The student's opinion on a topic is getting better and better as evidenced by the increasing number of sentences and the increasing use of cards.

5) Students' activities in eight kinds of activities increase sharply, especially speaking and writing activities

Cycle 2 was carried out in 3 meetings, with the material of the English Debate theory, debate material on the topic or motion "That the government would move the capital city". and the 3rd meeting the agenda of the 2 nd cycle of Debate activities

\section{Meeting 1}

Meeting 1 on Friday, 23 August 2019 with the material of asking and giving opinion which has been modified to become English Debate. The first meeting of cycle 2, the teacher, introduced the Time Token technique with English Debate. Of the 35 students in class XI AKL-1, all students attended. The teacher divides students into 12 groups. The previous groups were still used. After that, it was followed up with matching, namely the division of group pairs. Matching results are group 1 (positive) against group 5 (negative), group 2 (negative) against group 10 (positive), group 3 (positive) against group 11 (negative), group 4 (negative) against group 12 (positive), group 6 (positive) against group 9 (negative) and group 7 (negative) against group 8 (positive). The motion is the same, namely "that the government would move the capital of Indonesia"

The teacher explains how to conduct a debate, namely by contrasting a motion seen from the perspective of the group that agrees with the motion (affirmative or positive group) and the opposition group (negative). To agree or oppose there must be a division of tasks or a point of view. From one motion there will usually be two or more points of view. 
The next activity is to explain the flow of debate activities. The debate starts with the first speaker from the positive group and followed by the first speaker from the negative group, then the second speaker from the positive group, followed by the second speaker from the negative group, and then the third speaker from the positive group will be followed by speakers from the negative group.

Then the groups will work together to compile their respective speeches. There must be an agreement between speakers one two and three. The speaker should also not repeat the speaker's previous examples or arguments. The usage of the cards is still on going with the count of the number of cards down to 6 so that the maximum time is 90 seconds

\section{Meeting 2 and Meeting 3}

The second meeting was, was for assessment of debating activities and recording student activities. The topic used is still the same, namely "That the government would move the capital city". The third meeting was also tocomplete the debate

The observation results in cycle 2 were recorded in the prepared observation sheet. From the results of observations of student activities by observer 1, the following data were obtained:

Table 5.Observation results of student learning activities in cycle 2

\begin{tabular}{cccc}
\hline NO & Kind of activities & Percentage & Criterion \\
\hline 1 & Visual activity & $81 \%$ & High \\
2 & Oral activity & $86 \%$ & Very High \\
3 & Listening activity & $77 \%$ & High \\
4 & Writing activity & $88 \%$ & Very High \\
5 & Drawing activity & $75 \%$ & Moderate \\
6 & Motor activity & $77 \%$ & High \\
7 & Mental activity & $80 \%$ & High \\
8 & Emotion activity & $77 \%$ & High \\
\hline
\end{tabular}

The data was obtained from the observations of observer 1 during cycle 2 at the second meeting to the third meeting. From the data it can be seen that student activity during learning is in the high category (80\%). Visual activity in high category $(81 \%)$, oral activity in high category $(86 \%)$, better than during cycle1, namely $81 \%$, listening activity in high category $(77 \%)$, writing activity in very high category $(88 \%)$, drawing activity is moderate category $(75 \%)$ because there 
are almost not many drawing activities. High category movement activity (77\%), high category thinking activity $(80 \%)$ and emotional activity are high category $(80 \%)$. What stands out the most is that students are more skilled at expressing opinions and responding to other students' opinions. The number of cards students used also increased (on average more than 5 cards). Writing activity is also getting higher $(88 \%)$. This can be understood because students are getting used to writing their opinions in advance and the faster they do it. The student test results in Cycle 1 are as follows:

Table 6. Cycle Test Results 1

\begin{tabular}{clcc}
\hline NO. & \multicolumn{1}{c}{ Remark } & $\begin{array}{c}\text { Score/number } \\
\text { of students }\end{array}$ & Percentage \\
\hline 1 & Highest Score & 90 & \\
2 & Lowest score & 73 & \\
3 & Average & 81 & $97 \%$ \\
4 & Number of students reach the mastery & 34 & $3 \%$ \\
& level & & \\
5 & Number of students don't reach the & 1 & $81 \%$ \\
6 & mastery level & & \\
\hline
\end{tabular}

The results of the second cycle test showed that the average score obtained by students was 81 with the highest score of 90 and the lowest score of 73 . The number of students who completed learning was $97 \%$ of students who received a minimum score of 75 . For classical completeness, it was obtained $81 \%$ which means $81 \%$ of the material given absorbed by students. Thus, cooperative learning of the Time Token technique brings better results.

From the results of the analysis of the results of the action and the data obtained in the implementation of cycle 2 activities, it can be reflected as follows:

1) At the first meeting students still have difficulty in speaking order. This is understandable because they are still debating this for the first time. But at the second and third meeting it got better.

2) At the first meeting there was still not much group cooperation in defending opinions or arguments. The speaker is still focused on personal arguments.

3) In the beginning, not many were able to refute the arguments of the opposing group. However, at the second and third meetings there were rebuttals and defended or defended the arguments of his teammates.

4) The use of cards is getting smoother. The speaker is also familiar with the warning sound delivered by the time keeper so that when he hears a knock, the student as the speaker must immediately hand over or put down a card.

5) The time to talk is longer because they are more fluent in expressing their opinions and the more skilled they are in writing their ideas.

\section{Discussion}


Based on the data analysis, the results showed that there was an increase in learning activities through the Time Token technique on the topic of asking and giving opinion to students of class XI AKL-1 Semester 1 SMK Negeri 2 Temanggung in $2019 / 2020$ by $2 \%$ which is illustrated in the following table:

Table 7. Comparison of learning activities in cycle 1 and cycle 2

\begin{tabular}{|c|c|c|c|c|c|c|}
\hline & & $\begin{array}{c}\text { Percen } \\
\text { tage }\end{array}$ & Criterion & $\begin{array}{c}\text { Percen } \\
\text { tage }\end{array}$ & Criterion & \\
\hline 1 & Visual activity & $80 \%$ & High & $81 \%$ & High & $1 \%$ increase \\
\hline 2 & Oral activity & $81 \%$ & High & $86 \%$ & $\begin{array}{l}\text { Very } \\
\text { High }\end{array}$ & $5 \%$ increase \\
\hline 3 & Listening activity & $76 \%$ & High & $77 \%$ & High & $1 \%$ increase \\
\hline 4 & Writing activity & $83 \%$ & High & $88 \%$ & $\begin{array}{l}\text { Very } \\
\text { High }\end{array}$ & $5 \%$ increase \\
\hline 5 & Drawing activity & $74 \%$ & Moderate & $75 \%$ & Moderate & $1 \%$ increase \\
\hline 6 & Motor activity & $76 \%$ & High & $77 \%$ & High & $1 \%$ increase \\
\hline 7 & Mental activity & $79 \%$ & High & $80 \%$ & High & $1 \%$ increase \\
\hline 8 & Emotion activity & $76 \%$ & High & $77 \%$ & High & $1 \%$ increase \\
\hline & Average & $78 \%$ & High & $80 \%$ & High & $2 \%$ increase \\
\hline
\end{tabular}

The increase in student learning activities can be described in the following diagram:

$$
\text { Cycle } 1 \quad \text { Cycle } 2 \quad \text { Remark }
$$

NO Kind of activities

Figure 2. Diagram of increasing student learning activities 


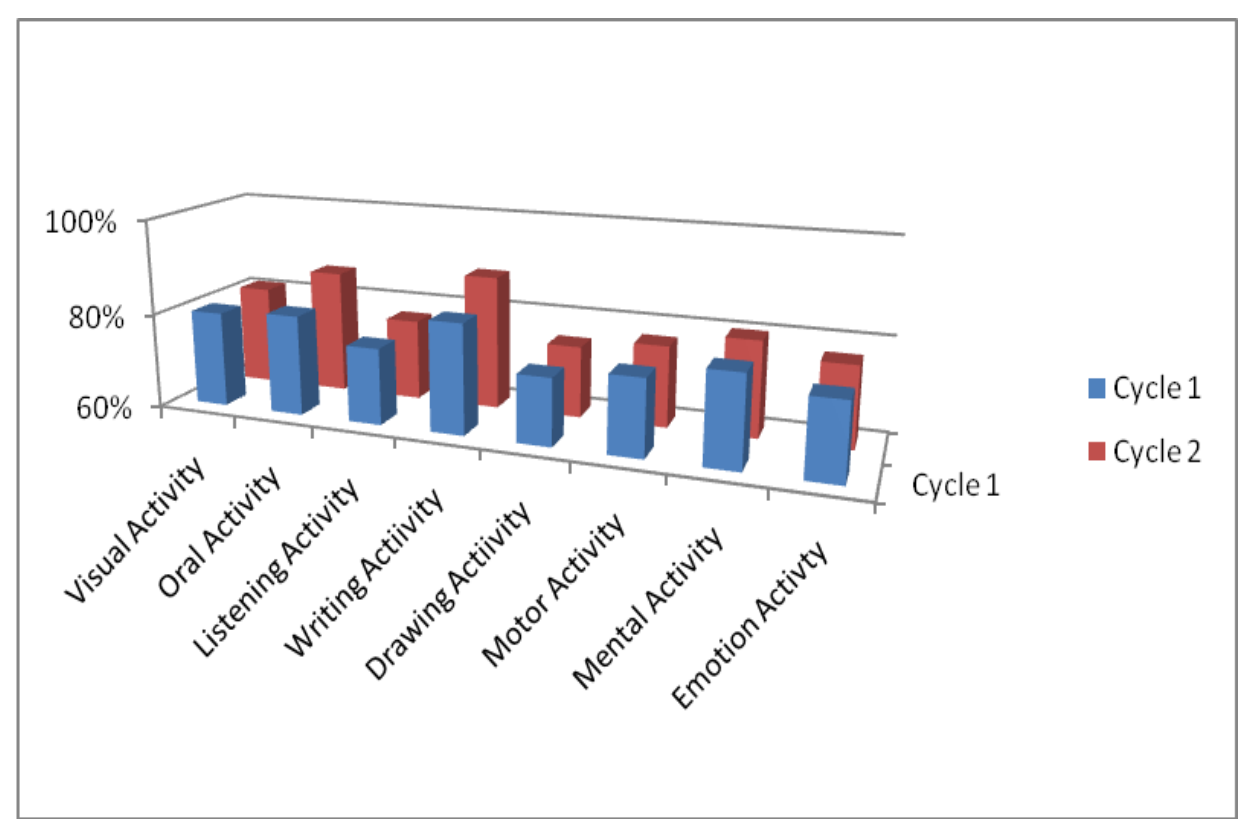

It can be seen in the table that there is an increase in 8 types of student learning activities from the first cycle to the second cycle. Visual activity in cycle 1 students have high activity, this means that most students have done visual activities. By paying attention to the presentation of friends from other groups in expressing opinions, arguing, asking other students, there was an increase of $1 \%$.

The category of oral activities was very high, increasing from $81 \%$ to $86 \%$. This shows that more and more students are trying to express their opinions and use more time and use more cards. This is also reflected in group discussion activities, as well as debates between groups, where students are more courageous in expressing their opinions or arguing against their opponents (in debate). Listening activity in cycle 1 was in the high category after the implementation of cycle 2 the activity increased $1 \%$ to $77 \%$. This activity includes the activities of students listening to the teacher's explanation, listening to other students' opinions, listening to the arguments of other groups. Writing activity increased by $5 \%$, from the high category to the very high category (88\%). Writing activities appear in making texts or drafts of debate opinions and arguments as well as recording opposing arguments in the debate. Drawing activity was not so prominent because there were not many drawing activities so it was only in the moderate category both in cycle 1 and cycle 2 . The movement activity increased slightly from $76 \%$ to $77 \%$. Included in this activity are discussing, conducting debates in front of the class, looking for words in the dictionary, and so on.

Thinking activity was in the high category and increased slightly from $79 \%$ to $80 \%$. Thinking about the words to be used, formulating correct sentences, thinking up rebuttals for the opposing team, defending arguments and devising debate strategies are examples of thinking activities. Meanwhile, emotional activity increased from $76 \%$ to $77 \%$, which is still in the high category. Changes in enthusiasm for searching words with a dictionary, enthusiasm for discussion, 
expressing opinions is high. The average talk time increased from pre-cycle to cycle 1 increasing from 19 seconds to 35 seconds and again increasing to an average of 81 seconds. The enthusiasm for completing the task is very prominent. This is made possible by tokens or rations that are given evenly and no student dominates the conversation. Thus the increase in learning activities through the Time Token technique on the topic of asking and giving opinion of class XI AKL1 Semester 1 SMK Negeri 2 Temanggung in 2019/2020 was 2\%.

Improved learning outcomes through the Time Token technique on the topic of asking and giving opinion of class XI AKL-1 1st semester SMK Negeri 2 Temanggung Year 2019/2020

Table 8. Comparison of the results of the test cycles 1 and 2

\begin{tabular}{|c|c|c|c|c|c|c|}
\hline NO. & $\begin{array}{l}\text { Remark } \\
\text { Highest Score }\end{array}$ & $\begin{array}{l}\text { Cycle } 1 \\
\text { Score/number } \\
\text { of students }\end{array}$ & $\%$ & $\begin{array}{l}\text { Cycle } 2 \\
\text { Score/number } \\
\text { students }\end{array}$ & of & $\%$ \\
\hline 1 & Highest score & 85 & & 90 & & \\
\hline 2 & Lowest score & 72 & & 73 & & \\
\hline 3 & Average & 78 & & 81 & & \\
\hline 4 & $\begin{array}{l}\text { Number of students } \\
\text { reach the mastery } \\
\text { level }\end{array}$ & 31 & $89 \%$ & 34 & & $\begin{array}{l}97 \\
\%\end{array}$ \\
\hline 5 & $\begin{array}{l}\text { Number of students } \\
\text { don't reach the } \\
\text { mastery level }\end{array}$ & 4 & $11 \%$ & 1 & & $3 \%$ \\
\hline 6 & Classical mastery & & $\begin{array}{l}78 \\
\%\end{array}$ & & & $81 \%$ \\
\hline
\end{tabular}

The increase in student learning outcomes is shown by the following diagram:

Figure 3. Diagram of increasing student learning activities 


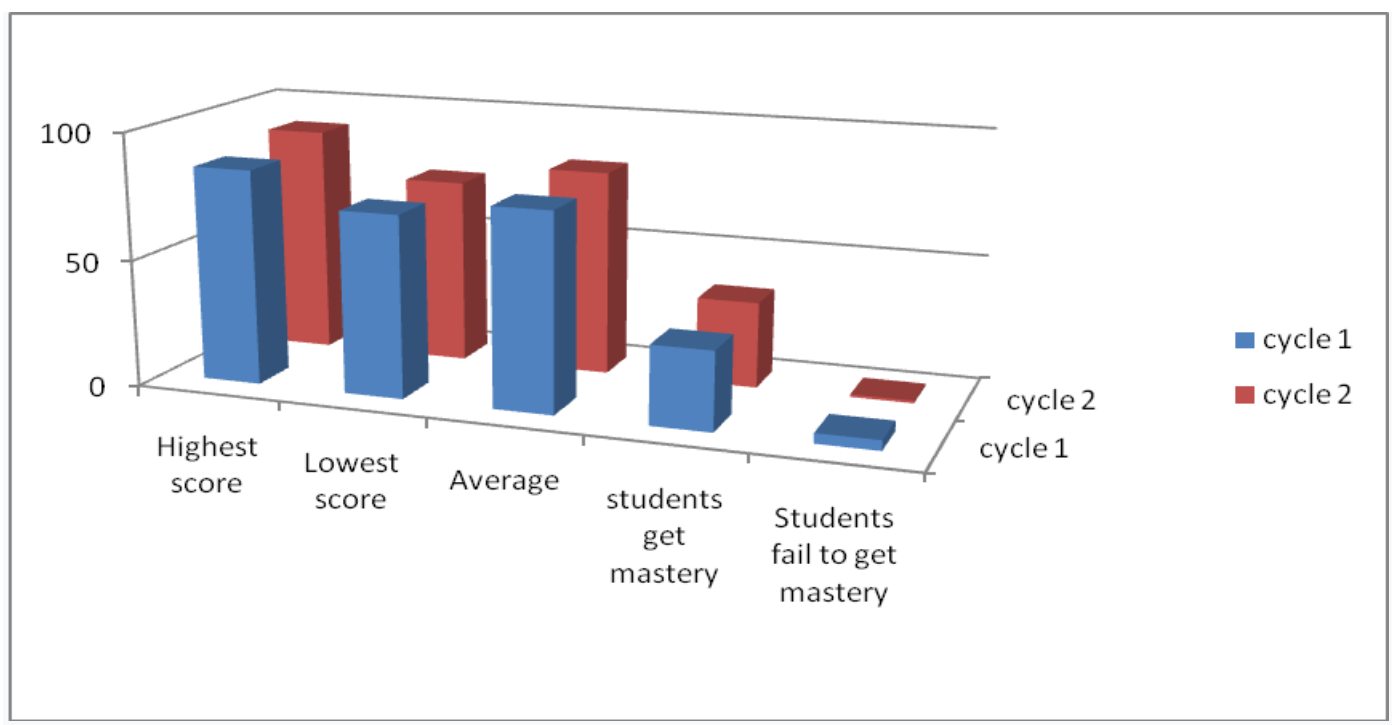

Based on the research results as shown in the table, there is an increase in communicative competence in speaking English, namely the lowest score increases by 1 point from 72 to 73 on individual tests. The average individual test score increased by 3 points from 78 in cycle 1 to 81 in cycle 2 . Completeness of classical learning on individual tests also increased by $8 \%$ from $89 \%$ to $97 \%$. While classical completeness increased from $78 \%$ to $81 \%$. Thus the increase in learning outcomes through the Time Token technique on the topic of asking and giving opinion of class XI AKL-1 Semester 1 SMK Negeri 2 Temanggung in 2019/2020 was $3.0 \%$.

\section{CONCLUSION AND SUGGESTION}

Based on the results of research and discussion of classroom action research, it can be concluded that:

1. Learning activities are increased through the Time Token technique on the topic of asking and giving opinion of class XI AKL-1 1st semester students of SMK Negeri 2 Temanggung in 2019/2020,

2. Learning outcomes are increased through the Time Token technique on the topic of asking and giving opinion of class XI AKL-1 1st semester SMK Negeri 2 Temanggung Year 2019/2020.

Based on the results of this study, there are several suggestions that need to be considered, including:

For Teachers; a) Time Token is better more often used on other topics so that students can quickly improve their communicative speaking competence, b) Teachers of other subjects should try the Time Token technique, especially for Indonesian, Javanese or other languages, c. The duration of a Time Token card can be changed from 15 seconds to 20 seconds or 30 seconds, especially for Indonesian. 
For Students : Students should not be afraid to make mistakes in expressing opinions because the most important thing is to convey opinions so that they reach the listener, not whether the sentences used are correct or not.

\section{REFERENCES}

AS Hornby, (1973). Oxford Advanced Leaner's Dictionaryof Current Englis. London:OxfordUniversity Press

Brown, H.D. (2004). Language Assessment: Principles and Classroom Practice. San Fransisco: Fransisco State University

Canale, M (1983) From communicative competence to communicative language pedagogy. In: Richards J, Schmidt R (eds) Language and Communication. London: Longman

Djumarah, S.B. (2013). Strategi belajar mengajar. Rineka Cipta, Jakarta

Hamalik, Oemar. (2013). Proses Belajar Mengajar. Jakarta : PT Bumi Aksara.

Henry Guntur Tarigan, (1990).Pengajaran Kompetensi Bahasa:Bandung: Angkasa

Jason Beale, Is Communicative Language Teaching A Thing Of The Past?, retrieved from http://www.jasonbeale.co m/essaypages/clt_essay.html.On 15 Maret 2019 at 17.14 WIB.

Sandra Savignon, (1983).Communicative Competence: Theory and Classroom Practice Massachusetts: Addison Wesley Publishing

Sardiman, A. (2011). Interaksi dan Motivasi Belajar Mengajar. Jakarta: Rajawali Pers.

Slavin, R. E. (2005). Cooperative Learning. Bandung: Penerbit Nusa Media.

Suprijono, Agus. (2015). Cooperative Learning. Teori dan Aplikasi PAIKEM. Yogyakarta: Pustaka Pelajar.

Sutikno, S. (2014). Metode \& Model-model Pembelajaran. Lombok: Holistica.

Zainal Aqib. (2009). Penelitian Tindakan Kelas Untuk Guru. Bandung: Yrama Widya

www.teachingenglish.org.uk accessed on March 15 Maret 2019 at 20.14 WIB 